\title{
Correction to: The time of concentration application in studies around the world: a review
}

\author{
Aleska Kaufmann Almeida ${ }^{1}$ Isabel Kaufmann de Almeida ${ }^{1}\left[\right.$. José Antonio Guarienti ${ }^{1} \cdot$ Sandra Garcia Gabas $^{1}$
}

Published online: 20 December 2021

(c) Springer-Verlag GmbH Germany, part of Springer Nature 2021

\section{Correction to: Environmental Science and Pollution Research https://doi.org/10.1007/s11356-021-16790-2}

The equations in Table 13 were not formatted correctly in the original proof.

The Original article has been corrected.

Publisher's note Springer Nature remains neutral with regard to jurisdictional claims in published maps and institutional affiliations.

The online version of the original article can be found at https:// doi.org/10.1007/s11356-021-16790-2

Isabel Kaufmann de Almeida isabel.almeida@ufms.br

Aleska Kaufmann Almeida aleska.kaufmann@gmail.com

1 Faculty of Engineering, Architecture and Urbanism and Geography, Federal University of Mato Grosso do Sul, Campo Grande, MS 79070-900, Brazil 